\title{
TERRITORIAL AND LINGUISTIC DEMARCATIONS IN THE DISPOSITIF KÄRNTEN/KOROŠKA
}

\section{ROLAND W. PEBALL AND KLAUS SCHÖNBERGER}

In southern Carinthia (Kärnten/Koroška), a conflict over the rights and oppression of the Slovenian-speaking minority has been smoldering for one hundred years, since the military border conflict of 1918/19 and the plebiscite agreed upon in the Treaty of St. Germain. The plebiscite was on the question of whether southern Carinthia should join the rump state of the former Habsburg monarchy, German-Austria, or the newly created SHS. In 1920, the majority of the resident population (both the German Carinthians and the Slovenian minority) decided in favor of Austria. In the following decades an unrelenting struggle for language and memory was waged by German-nationalist-minded representatives of the German Carinthian majority against the minority. This article 1 analyzes the thematization of linguistic and territorial demarcations in the dispositif Kärnten/Koroška. Keywords: dispositif, Kärnten, nationalism, contentious cultural heritage
Na južnem Koroškem (Kärnten/Koroška) že sto let tli konflikt o zatiranju in pravicah slovensko govoreče manjsine, to je vse od vojaskega obmejnega spopada 1918/19 in plebiscita, dogovorjenega s senžermensko pogodbo. Plebiscit se je nanašal na vprašanje, ali naj se južna Koroška pridruži okrnjeni nekdanji habsburški monarhiji ali novoustanovljeni državi Srbov, Hrvatov in Slovencev. Leta 1920 se je večina tamkajšnjega prebivalstva (tako nemške kot slovenske skupnosti) odlocila za Avstrijo. V naslednjih desetletjih so se nemško nacionalistično usmerjeni zastopniki nemške koroške večine neusmiljeno borili za jezik in spomin proti manjšini. Članek analizira tematizacijo jezikovnih in teritorialnih razmejitev z vidika dispozitiva Kärnten /Koroška.

Ključne besede: dispozitiv, Koroška, nacionalizem, sporna kulturna dedišcina

In southern Carinthia (Kärnten/Koroška), a conflict over the rights and oppression of the Slovenian-speaking minority has been smoldering for one hundred years. This dispute is particularly centered on the remembrance and commemoration of the military border conflict of 1918/19 and the plebiscite agreed upon in the Treaty of St. Germain. When the successor states of Austria-Hungary emerged after the First World War, this military conflict was fought out between irregulars sympathetic to the Kingdom of Serbs, Croats, and Slovenes (SHS) and German Austrian private paramilitary groups (Freikorps) as well as local defense companies (Heimwehr) or social democratic workers' battalions (cf. Lagger, 1930: 129). The plebiscite was on the question of whether southern Carinthia should join the rump state of the former Habsburg monarchy, German-Austria, or the newly created SHS. In 1920, the majority of the resident population (both the German Carinthians and the Slovenian

1 This article is based on the results of the Austrian FWF-funded project "Performing Reality: Disand Re-Articulation of the Carinthia/Koroška Dispositif. A Co-Production between Arts-Based and Cultural Science Research on the Occasion of the Centenary of the Carinthian Plebiscite" (http:// volksabstimmung2020.aau.at). We would like to thank Fabian Ziemer (Hamburg) and especially Ute Holfelder (Klagenfurt) for the discussion and critical comments at the "Kolloquium in der Kammer" at the Institute for Cultural Analysis at the Alpen-Adria-University of Klagenfurt. 
minority) decided in favor of Austria. In the following decades, up to the era of Jörg Haider (as Carinthian governor), an unrelenting struggle for language and memory was waged by German-nationalist-minded representatives of the German Carinthian majority against the minority. With the apology to the minority expressed by Austrian President Alexander van der Bellen in his speech on the centenary of the plebiscite on October 10, 2020 in the presence of the Slovenian president to the Carinthian Slovenians for non-compliance with legal claims as well as numerous deferrals and exclusions (Van der Bellen, 2020), a turning point might have been reached by now. This article analyzes the thematization of linguistic and territorial demarcations in the dispositifKärnten/Koroška. In doing so, we also ask what analytical yield the theoretical concept of the dispositif Kärnten/Koroška proposed by us is able to provide for both the genealogy and transformations of the conflict. ${ }^{2}$

\section{THE CONFLICT BETWEEN KÄRNTEN AND KOROŠKA}

The conflict in Carinthia was (and still is) fought at various social levels. In the cultural field, the disputes concerned or concern, for example, language practices, clubs and societies, festive culture, and songs, and at the state level the conflict over Article 7 of the Austrian State Treaty of $1955,{ }^{3}$ school policy, and state and municipal symbols of sovereignty such as place-name signs. Special importance is attached to the politics of remembrance and commemoration, as manifested in the occupation of public space and the landscape through commemorative plaques and the erection of monuments, and also in marking the provincial holiday on October 10.

The potency of the conflict became apparent in everyday life in ongoing disputes over the use of Slovenian at school and in public spaces (cf. Knight, 2020). In 2020, on the hundredth anniversary of the plebiscite, the "defensive struggle" was still commemorated in numerous ceremonies on October 10. This day does not stand as a holiday for an act of plebiscitary democracy, women's suffrage, or polyphony through multilingualism (and this is still passionately debated), and the controversies surrounding October $10^{4} \mathrm{can}$ be read as an example of contentious cultural heritages (Hamm, 2021a: $130 \mathrm{ff}$.). ${ }^{5}$ This designation refers to an asymmetrical relationship in which the memory of the minority

2 The argumentation on the concept of the dispositif presented in this text builds on a previous article in German, which, however, has a different thematic orientation (cf. Peball, Schönberger, 2021).

3 Article 7 of the Austrian State Treaty of 1955 concerns the "rights of the Slovenian and Croat minorities" (cf. BGBl no. 152/1955, https://www.ris.bka.gv.at/eli/bgbl/1955/152/A7/NOR12005177).

4 Cf. the brochure by Klubs slowenischer Student*innen (2020), and the identically named series of events and counterdemonstration on October 10, 2020. Cf. ORF-Kärnten (Chronik): Gegendemo und Reaktionen auf Festakt, October 10, 2020 (https://kaernten.orf.at/stories/3070801/).

5 In the context of heritage research, the term contentious cultural heritages attempts to operationalize the implications of Chantal Mouffe's concept of agonism: "The proposal to make heritage contentious aims at unsettling dominant discourses that silence, exclude, or marginalize certain positions by 
is systematically made invisible. ${ }^{6}$ It is such politics of memory (cf., e.g., Nemec, 2012), led by means of heritage discourses, that establishes conflictual negotiation processes and constantly feeds them anew.

A central theme in this conflict was, for example, the assertion of threatening Slovenianization and the invention of an alleged "primal fear" (Urangst) of the German Carinthian population in this context. This threat was justified by the military border conflict of 1918/19 and the invasion of the Yugoslav Army (i.e., Tito's Partisans) in 1945. However, the invasion in 1945 was preceded by war crimes (e.g., in Begunje) and annexations by the Nazi armed forces (Wehrmacht). Given the deportation of the Carinthian Slovenians (1942), this is a classic victim-perpetrator reversal. The assertion of the threat to the territorial border is one of the constitutive elements for the legitimization of an everyday linguistic civil war against the Carinthian Slovenians. Bernhard Perchinig speaks of the fact that, after the plebiscite, downright revenge was taken and thus the democratic idea was denied:

Thus, the democratic character of a plebiscite was reduced to absurdity! In a plebiscite, both parties campaign with equal right for their goals; the voters vote with equal rights for one or the other alternative. If those who lost the vote are persecuted afterwards, the democratic character of the vote is disregarded. (Perchinig, 1984: 94; also cf. Knight, 2020: 17) ${ }^{7}$

In terms of memory politics, this persecution sometimes takes on the dimensions of a damnatio memoriae: the share and participation of the Partisans from the Slovenian minority as the only noteworthy military factor in the resistance against the Nazi armed forces and in the liberation from Nazism on the side of the Yugoslav Army is still banished from German Carinthian memory (cf. Schönberger, 2021a). This memory (or non-memory) and the sometimes systematic disparagement of the anti-Nazi resistance, as well as the repeatedly burgeoning dispute over (linguistic) minority rights, point to a network of discourses, practices, and institutions. Actors of remembrance such as the Kärntner Geschichtsverein (Carinthian Historical Society), the Kärntner Abwehrkämpferbund (KAB: Carinthian Defence Fighters' Association) or the Kärntner Heimatdienst (KHD: Carinthian Homeland Service), as well as municipal administrations, schools, and associations on the one hand,

combining research, practical heritage work, and creativity." Marion Hamm (2021a: 145) emphasizes that the aim must be to do justice to the political dimension of contested cultural heritage.

6 Central to the discussion of a dispositif Kärnten/Koroškais Marion Hamm and Janine Schemmer's observation that the conflicts inscribed in power relations are not necessarily public in the hegemonic discourse: "Conflicts inscribed in the power-relations between silencing and un-silencing are not necessarily articulated in public discourse, and the selective silencing of heritages is not always openly contested - but they are always present in strategies of silencing and un-silencing" (Hamm, Schemmer, 2021).

7 German quotations have been translated into English by the authors. In the case of Michel Foucault, an attempt was made to use English-language editions. 
and minority activists on the other hand, attract each other and at the same time repel each other. They form a conflicting network that is interrelated in many ways, which we refer to and examine below as the dispositif Kärnten/Koroška (cf. Liepold-Mosser, 2020).

\section{THE DISPOSITIF AS AN ANALYTICAL INSTRUMENT OF KNOWLEDGE}

We use the term dispositif according to Michel Foucault's ${ }^{8}$ intention "of not-of no longer - treating discourses as groups of signs [...] but as practices that systematically form the objects of which they speak" (Foucault, 1972: 49). In an oft-cited definition, Foucault identifies three characteristics of the concept of the dispositif. First, a dispositif consists of a heterogeneous ensemble of elements "consisting of discourses, institutions, architectural forms, regulatory decisions, laws, administrative measures, scientific statements, philosophical, moral and philanthropic propositions - in short, the said as much as the unsaid" (Foucault, 1980: 194). Second, he characterizes a dispositive as a network (or system) of relations between these elements, whereby his aim is to focus on the nature, the quality of these connections and relationships, between which (whether discursive or not) there is an "interplay of shifts of position and modifications of function" (ibid.: 195). Third, Foucault understands a dispositif as a strategic formation, "which has as its major function at aiven historical moment that of responding to an urgent need" (ibid.).

Following Magdalena Nowicka (2013: 51), we find the concept of the dispositiffruitful as an analytical instrument of knowledge when it is a matter of making visible multilayered, historically evolved connections and relationships (networks) between linguistic (discursive) and material (non-discursive) elements, as well as the links between practices, artefacts, institutions, and knowledge about them, which would otherwise be lost from view.

The openness of the concept of the dispositif, however, bears the risk of arbitrariness in its use. For us, the concept of the dispositif seems particularly informative in the sense of a research perspective (Bührmann, Schneider, 2008: 14-21), from which we try to link hegemonic and subaltern minority narratives, practices, and "institutional materializations" (Keller, 2011: 138) and to consider them as a complex. The dispositifKärnten/Koroška does not refer to Carinthia in its entirety as a geographical, cultural, or social space, let alone

8 The concept of the dispositif is part of Foucault's later discourse theory, in which he increasingly turned to the material level of discourse and subjects. In The Archaeology of Knowledge (1969) and earlier texts, Foucault had consciously neglected subjects in their function as productive instances (i.e., as active and intentionally acting social actors) and dealt with the "excavation" and reconstruction of orders of knowledge and the systems of rules of the discursive formations of past epochs. As a result, his attitude toward the subject changed. He began to concern himself with complexes of power and knowledge, in which both are directly and constitutively connected. According to him, this determines the forms and areas of all knowledge (Foucault, 1995: $27 \mathrm{ff}$.). In the course of re-accentuating his theoretical program, Foucault's focus shifts from the level of discursive formations and propositional systems to the mode in which discourses unfold their effect in the world (cf. Keller, 2011: 138). 
in its visible and invisible manifoldness. The dispositif Kärnten/Koroška denotes a complex, multilayered, and often contradictory ensemble of real and abstract elements, of contexts that entwine around an eidolon of what or how Carinthia was, is, or should be. Carinthia takes on partly obscure, inconsistent, and contradictory forms. The aim of our approach is to analyze these misperceptions and illusions, their consequences, and their implications for both individuals and groups.

\section{THE DISPOSITIF KÄRNTEN/KOROŠKA}

\section{DEFINITION AND GENESIS}

We understand the dispositif Kärnten/Koroška as "ensemble of elements"—of discourses, practices, and artefacts - as well as the network of relations between these elements that responded to the "urgent need" that arose in the course of the so-called Carinthian defensive struggle of 1919/20 and the plebiscite of 1920. The institutional and discursive manifestation $^{9}$ of the conflicts around identity and difference in relation to borders and language, among other things, contained in the term dispositif Kärnten/Koroška refer to both their genesis and their currently impending demise.

In order to examine the analytical substance of this specific dispositif, it is necessary to describe how it functions: First of all, we can determine its main purpose and the historical moment at which it emerged. According to Bernd Liepold-Mosser, the dispositif Kärnten/ Koroška "came into the world" as a historical a priori with the events in Carinthia after 1918 (Liepold-Mosser, 2020: 10). Central elements of the dispositif are the narratives about the plebiscite of 1920 as a consequence of the military border conflict that took place beforehand, which on the part of the hegemonic German Carinthians, in large part German-nationalist (see below) historiography (Kärntner Wissenschaft 'Carinthian science'), ${ }^{10}$ are described as the Carinthian defensive struggle or struggle for freedom.

\section{THE DISPOSITIF AS A MANIFESTATION OF DISCOURSES}

Subsequently, various discourses wrestled over the interpretation of these historical events. Already during the plebiscite, massive propaganda battles were fought between the proGerman Austrian and pro-SHS sides. Already at this point, the dispositif began to emerge as the discourses' "material and ideal infrastructure" (Keller, 2011: 235). This can be seen in the establishment of the national policy committee of the Carinthian parliament in

9 By the term manifestation, we mean the becoming visible of discourses in the sense of what Keller describes as the "materiality of discourses" or their "manifest appearance" (Keller, 2011: $252 \mathrm{ff}$.).

10 On the concept of Carinthian science, see Fritzl 1992 and Kuehs 2020. 
August 1919 with the Provincial Propaganda Directorship (Landesagitationsleitung, LAL), an organ that was to organize propaganda on the German Austrian side (Pluch, 1957). Later, the LAL gave rise to the initially cross-party association Kärntner Heimatdienst or KHD (Carinthian Homeland Service). After the Social Democrats left the association in 1925, it was renamed the (Kärntner Heimatbund, oder KHB, Carinthian Homeland Association). In the interwar period, the KHB was not only the driving force behind the Germanization policy, but it also served as a rallying point for the supporters of the Austrian NSDAP, which was illegal from 1933 to 1938. After the State Treaty of 1955, the association was re-established under the name Kärntner Heimat Dienst or KHD; Fritzl, 1990), and it still exists today. This organization can be seen as an element of the dispositif Kärnten/ Koroska. Likewise, it is evidence for the persistence of the dispositif to the present day. The operationalization of the propaganda of the KHD and KHB further clarifies the strategic function originally underlying the dispositif.

After the plebiscite, ${ }^{11}$ the discourse that we call "German nationalist" became hegemonic in official German Carinthian historiography. Its "mythical" narrative structure as well as its inherent intertwining of historiography and politics were explained by Wilhelm Kuehs (2020). The German nationalist variant of the German Carinthian discourse states that both the participation in the military border conflict and the result of the plebiscite were caused by the commitment to Germanness. From this was derived the legitimization for the repressive (linguistic) assimilation pressure against the minority.

The manifestation of the German nationalist discourse-in other words, the formations of the underlying dispositif — can be seen, for example, in the multilayered interweavings between the continued existence of so-called traditional associations such as the KHD, the KAB, and the Kärntner Landsmannschaft (Carinthian Patriots) and the (ritualized) commemorative practices practiced by them. The corresponding interweavings are also evident during the annual October 10 celebrations (cf. Holfelder, 2021a), in specific historical events such as the signage dispute (Ortstafelsturm; Hamm, Schönberger, 2021b), and in the everyday hostile practices of parts of the majority population against the minority language as well as in related political ordinances and their interpretation (the constitution, official language, school, etc.). They also constitute the network that makes up the dispositif. They show how specific, historically "evolved" relations exist between ritualized celebrations of the anniversary of certain historical events, organizations of civil society (clubs and associations), and the official provincial policy, historiography, and political agenda. The power and knowledge relations are inscribed in this, by means of which the ideas and imaginations of Carinthia are invoked.

Another manifestation of the manifold links, interweavings, and strategic function of the dispositifKärnten/Koroška is the "occupation of the landscape" (Holfelder, Schönberger,

11 See the new election analysis by Tiemann (2020), which diagnoses above all economic causes for these decisions. 
2020) or the occupation of public space with street names, monuments, and commemorative plaques. Ute Holfelder (2020: 7) has shown the extent to which street names fulfill such a strategic function in the provincial capital of Klagenfurt: "The symbolic occupation of the formerly contested territory was also carried out by naming — mostly centrally locatedstreets in Carinthian towns and municipalities." Tellingly, it was Hans Steinacher ${ }^{12}$ that summed up this function in 1959: "Steinacher paid tribute to Maier-Kaibitsch's" work in the Kärntner Heimatbund, as he had achieved a great deal with his 'folklore work in Carinthia' - through the 'erection of historical commemorative signs from Carinthia's time of struggle, such as the affixing of commemorative plaques to all buildings in the "zone" in which the polling stations had been located on October 10, 1920."'14 It is not surprising that it is precisely such monuments and commemorative plaques that have become the target of those actors in the Carinthian dispositif that are to be made invisible by the hegemonic German Carinthian politics of remembrance (cf. Schönberger, 2021c).

\section{SUBJECTIFICATION AND SUBJECTIVATION IN THE DISCOURSE AND COUNTER- DISCOURSE OF THE DISPOSITIF KÄRNTEN/KOROŠKA}

The potency of the dispositif is also evident in its impact on subjects. As Magdalena Nowicka (2013: 48 ff.) suggests, the concept of the dispositifopens up further possibilities in analyses of the production of subjectivity, alluding to the duality of subjectification (Fr. assujettissement) as an expression of power over the individual and subjectivation (Fr. subjectivation) in the sense of a person's relationship to himself or herself. Subjectivity in the context of the concept of the dispositif, according to Foucault, always means two things: namely, both subjugation and individuation.

This ambiguity of the concept of the subject and its connection to power-respectively, the ambivalence between subjectification as subjugation on the one hand and subjectivation as a process of individuation on the other, whereby the one does not exclude but rather complements or even conditions the other-is already apparent in Foucault's work: "There are two meanings of the word 'subject': subject to someone else by control and dependence; and tied to his own identity by a conscience or self-knowledge. Both meanings suggest a form of power which subjugates and makes subject to" (Foucault, 1981: 781).

Considering the ambivalent relation of subjectification and subjectivation in Foucault's concept of the subject, it becomes possible to explain how the discourses associated with the dispositif Kärnten/Koroška are interwoven. It becomes explicable how these discourses

12 On the person of Hans Steinacher, see Schönberger (2021b).

13 Alois Maier-Kaibitsch was the central figure of the Nazi ethnic cleansing in 1942 (Fritzl, 1990: 21

ff.) and was sentenced to life imprisonment as a war criminal in 1947, but then released early in 1956 (cf. Elste, 1997).

14 Rundbrief des Alpenländischen Kulturverbandes 1959 (6), 1st letter/March 1959, 3 ff., quoted in Holfelder (2020: 7). 
not only constitute their objects in relation to each other, but to what extent they also condition persons and groups in their understanding of themselves and others, as well as including them in their actions (as actors) in the dispositif. ${ }^{15}$ Both in the German nationalist German Carinthian discourse and in the counter-discourse of the minority and its respective manifestations, there are connections and links that point to a unity of discourse and counter-discourse, which create a connection that "defines" the subjects and seems almost impossible for the participants to circumvent. Thus, discourses manifest themselves in the actions and performances of individuals and groups that identify with and are identified by them-both individuals (German Carinthians or Carinthian Slovenians) and, for example, the actors of the German or German nationalist traditional associations on the one hand. On the other hand, there are those of the Carinthian Slovenian interest groups, such as the Council of Carinthian Slovenians (Narodni svet koroških Slovencev) or the Association of Slovenian Organizations (Zveza slovenskih organizacij). In the process, persons and actors mutually refer to each other as well as to the discourses and their manifestation in the dispositifKärnten/Koroška. For this reason, discourse and counter-discourse in the dispositif Kärnten/Koroška can be understood as two sides of the same coin. This interweaving of discourse and counter-discourse in turn has direct repercussions on the self-understanding of the subjects.

The context that defines the subjects clearly emerges in the effectiveness of the hegemonic German nationalist discourse of the dispositif Kärnten/Koroška, to which the discourse of the minority must orient itself as a counter-discourse.

In the hegemonic discourse, subjectivizations of identities and differences were constructed and offered with political calculation and alongside institutional legitimations (such as those of the Carinthian Provincial Archives or the History Association for Carinthia, which as organizations are constitutive for "Carinthian science" and for the dispositifitself (cf. Kuehs, 2020).

In this context, internal boundaries - illustrated here by the example of the conflictual negotiation of language and identity within the dispositif — and external boundaries (hence, territorial borders and their construction) play an important role:

Every demarcation is an act of differentiation, which implies the constitution of meaning, just as every definition is based on the principle of bordering. The border differentiates, categorizes and hierarchizes and puts the differentiated units into relation with each other [...]. The establishment of borders is therefore of paramount importance for forming symbolic and social orders. It is through borders that units are determined as supposedly homogenous units and also put in relation to other units. (Doll, Gelberg, 2016: 17)

15 On the relationship between subject and discourse, see, e.g., Keller 2011 : 209-223. 
The term Grenzland 'borderland', which one stereotypically encounters in German nationalist discourse, ${ }^{16}$ does not become a constitutive element of self-description there by chance because the invocation of collective identities requires acts of demarcation and limitation in the sense of differentiation.

Alexandra Schwell notes that the concept of identity necessarily contains a boundary marking because "through mechanisms of categorization and self-categorization, a distinction is created between 'us' and 'the others"' (Schwell, 2008: 26). Accordingly, identity-forming processes are based on the drawing of borders

because it is only through these that difference can arise, that distinctions and categorizations can be made. And only by drawing borders can we distinguish ourselves from others and define something of our own. Borders are therefore inextricably linked to collective identities. (Schwell, 2021: 268)

\section{LANGUAGE POLICIES AS INTERNAL DEMARCATION AND THE INVOCATION OF COLLECTIVE IDENTITIES}

Within the dispositif, the delineation of internal borders runs primarily along the "diacritical feature" 17 of language. At the same time, through its adaptive changeability during the period of Nazism in Carinthia, this interpretive pattern illustrates the connection between German Carinthian-dominated (Nazi German) "Carinthian science" and Nazi cultural and Germanization policies. After October 10, 1920 and with the increasing hegemonization of German nationalist discourse and the establishment of the dispositif, speaking Slovenian became a criterion of social exclusion, but at the same time one of inclusion in or subjectification under the collective identity known as the Slovenian ethnic group.

Collective identities, however, are generally sui generis contradictory and, according to Lutz Niethammer, tend towards essentialism because they attempt to construct homogeneous collectives that are claimed to be natural but do not exist in this form (cf. Niethammer, 2000). ${ }^{18}$

From the perspective of discourse theory, such a collective identity can therefore be seen as a powerful (discursive) attribution or specification that results in processes of subjectification in the dispositif. 19 External attributions become the starting point and the

16 See, for example, the numerous publications with the term Grenzland in the title (cf. Feldner, 1982).

17 The notion of overt "diacritical features" as the "cultural content" of ethnic dichotomizations comes from Fredrik Barth (1998 [1969]: 14).

18 For Niethammer, one of the main contradictions in the semantic field of the concept of identity is that between an "asserted identity of essence of a collective, which objectifies it into a collective subject, and the [...] continuity of a differentiated and unique subject" (Niethammer, 2000: 54).

19 An example of such an attribution or fixation by the hegemonic discourse in the dispositif Kärnten/ Koroška by a representative of "Carinthian science” is Martin Wutte's Windisch theory (cf. Fischer, 2016). 
source of friction. The individuals that are subject to these attributions also appropriate them and reproduce them through their everyday actions. Because this appropriation always requires interpretation and is thus quite obstinate, it not only leads to constant changes in the discourses and in the dispositif, but it can also be used specifically as a "technology of the self" 20 to sublimate or even counteract attributions by others.

Counter-discourse becomes the minority's means of generating agency in delimiting (self-)descriptions, whereby an essential moment of counter-discourse-hence the name-is that it conflicts with the attributions and invocations of hegemonic discourse as well as its practices and rituals. ${ }^{21}$ When we point out that the dispositif Kärnten/Koroška is also co-created by the actions of the Slovenian minority, this in no way ignores the different power relations and the considerably smaller options for action of the Slovenian-speaking minority compared to the German Carinthian majority. The crux for the minority, however, is that those German nationalist forces that have a great interest in the social and political divisions underlying the dispositifKärnten/Koroška need the self-confident and vocal action of the minority in the counter-discourse to be able to perpetuate the dichotomy.

\section{CONFLICTS OVER LANGUAGE BETWEEN NAZI TERROR AND PRESSURE TO ASSIMILATE}

Immediately after the plebiscite of 1920, the pressure to Germanize was increased (cf. Grafenauer, 2016) and the expulsion and exodus of Slovenian-speaking intellectuals began. This policy reached its climax under Nazism, when 1,217 Carinthian Slovenians were forcibly deported and the commitment to Slovenian was threatened in Styria in 1944. Gauleiter Siegfried Uiberreither announced: "Whoever professes to be a Slovenian must expect to lose his family, home, shelter, and bread, and ultimately to be persecuted as an enemy of the state" (quoted in Moser, 1982: 20).

Within the framework of the "policy of assimilation" (Knight, 2020), the "destruction of bilingual elementary schools" (ibid.: 289 ff.) in the 1950s was a very central means of the German nationalist forces to push back Slovenian: "The Carinthian speaks German" was a slogan spread by the Nazis (Larcher, 1988: 8), but it was still widely propagated after 1945. Through numerous measures, the use of Slovenian was banned from the public

20 Foucault understands "technologies of the self" as those practical procedures and methods of individual mastery "which permit individuals to effect by their own means or with the help of others a certain number of operations on their own bodies and souls, thoughts, conduct, and way of being, so as to transform themselves in order to attain a certain state of happiness, purity, wisdom, perfection, or immortality" (Foucault, 1988: 18).

21 See, for example, the counterdemonstrations by young Carinthian Slovenians at the anniversary events on October 10,2020, who protested against a "one-sided German nationalist culture of remembrance" and the disappearance of Slovenian in Carinthia (Brunner, 2020). 
sphere. It was mainly in the areas of family and church that Slovenian could still be spoken (Jodelbaur, 1996: 127).

In fact, parts of the minority themselves internalized - more or less voluntarily - the disdain for their own language: "For a long time, German was regarded as the language of progress and Slovenian as backward." Bernard Sadovnik remembers what his sister and father had to experience: when he wanted to enroll his daughter in Slovenian lessons at school, his employer threatened him: if he did so, he would lose his job and his rented apartment (May 2020). There are numerous accounts from contemporary witnesses that remember the way in which the public use of Slovenian led to violent reactions and exclusions. It is above all former pupils of the Slovenian high school that remember many such situations.

In the conflict over bilingual place-name signs (from the early 1970s until 2011), the dispute over Slovenian became particularly manifest. Whereas multilingualism is often considered normal in the European context, it was stylized as a threat in Carinthia: "Carinthia's multilingualism is part of the entire European picture. The problem is not that Carinthia is multilingual; the problem is that many in Carinthia do not want to be multilingual" (Pelinka, 2004: 107).

Even if, in the meantime, the attitude toward bilingualism has changed in a large part of the German Carinthian population, as is shown by increasing enrollment in bilingual preschools and primary schools, there are still signs of the rejection of Slovenian in the public sphere, which, however, have become fewer overall due to the loss of importance of Slovenian in general. ${ }^{22}$

The student film project Sledi - Spuren (2020) explores this issue. On the one hand, the relentlessness of the historical pressure of Germanization is revealed in the interviews with contemporary witnesses, but also a continuing lack of understanding and the pain of a younger generation of Carinthian Slovenians due to the massive loss of language that can be observed. ${ }^{23}$

\section{CONSTRUCTING THE NATURAL “GEOGRAPHICAL UNITY” OF CARINTHIA}

While the focus so far has been on internal demarcations using the linguistic aspect as an example, the following section deals with external demarcations, territorial and geographical borders, and their construction. We cannot assume a dichotomous separation here because, in the case of Carinthia, language or language policy and geography coincide in the

22 See the field reports in Klubs slowenischer Student*innen (2020: 80-85).

23 ORF Volksgruppenradio: Let's go viral! Dem Sprachverlust in einem Roadmovie auf der Spur. 3.1.2021. The film is available on YouTube: https://www.youtube.com/watch?v=YKSIDvBpwag\&t=9s. 
sense of a "linguistic landscape." ${ }^{4}$ This can be seen in the aforementioned occupation of public space and the place-name sign conflict, as well as, for example, in the toponomastic work of the dialectologist Eberhard Kranzmayer, who headed in the Institut für Kärntner Landesforschung (IKLF: Institute for Carinthian Regional Research at the University of Graz). The IKLF had been founded as part of Heinrich Himmler's ancestral heritage (NS-Ahnenerbe) think tank-appropriately enough on the anniversary of the referendum in Klagenfurt, on October 10, 1942.

For Klemens Wagner and Jan David Zimmermann, Kranzmayer's linguistic cartography in his unfinished Dialektatlas Österreichs und seiner Nachbarländer (Atlas of the Dialects of Austria and Neighboring Countries) and its connection to Nazi spatial politics must be viewed in a differentiated manner and in the light of 'völkische Wissenschaft' ('völkisch science'). This means taking into account the social circumstances of its creation, whereby völkisch 'racial, ethno-nationalist' covers a broader (and longer-term) spectrum than National Socialist. Wagner and Zimmermann point to the disciplinary relation between dialect research and cultural geography, especially in their focus on research on peoples and their supposed cultural rootedness in the soil (Volks- und Kulturbodenforschung; cf. Wagner, Zimmermann, 2020). ${ }^{25}$

As noted above, the last ten years have also seen a lot of movement at the government level in Carinthia, the ossified fronts are losing their power of orientation, and the historically grown order of knowledge, as it was and still is expressed in the Carinthian dispositif Kärnten/Koroška, is in the process of crumbling. Nevertheless, certain "interpretive patterns,"26 which already have their origins in the völkisch-oriented and German Carinthian or German nationalist science in Carinthia after 1920 and thus the beginnings of the dispositif, persist.

An example of such an interpretive pattern and the territorial demarcations in the dispositifKärnten/Koroškais that of the naturalization of Carinthia's (external) borders, whereby Carinthia in its present form is described as a naturally limited, indivisible space, analogous to the motto of the commemorations of October 10: "Carinthia free and undivided." At the same time, through its adaptive changeability during the period of Nazism in Carinthia,

24 The term linguistic landscape "refers to the visibility and salience of languages on public and commercial signs in a given territory or region. It is proposed that the linguistic landscape may serve important informational and symbolic functions as a marker of the relative power and status of the linguistic communities inhabiting the territory" (Landry, Bourhis, 1997).

25 “This line of research designated [...] as 'German national soil' all those geographical areas wherever 'Germans' settled and interpreted as German cultural soil all those regions where 'Germans' had once settled. This could also be eastern Europe, for example, and the Germanic peoples were also considered 'Germans' in this context” (Wagner, Zimmermann, 2020).

26 The term interpretive pattern is used here in its sociological and discourse-analytical definition following Reiner Keller. Basically, it refers to "figures of interpretation that are used in concrete acts of interpretation and are manifested in different linguistic-material forms. Furthermore, the term pattern also means that several quite different elements of knowledge or interpretation and evaluative components are linked here" (Keller, 2011: 240). 
this interpretive pattern illustrates the connection between German Carinthian-dominated (Nazi German) "Carinthian science" and Nazi cultural and Germanization policies.

In his commemorative speech on October 10, 2018, the mayor of Völkermarkt, Valentin Blaschitz (Social Democratic Party of Austria, SPÖ), emphasized that the Carinthians had drawn their strength for the "heroic fight for freedom" and the successful referendum, among other things, from their love for Carinthia and its "beautiful landscape, so clearly delineated by nature and created as one unit." ${ }^{27} \mathrm{He}$ reminded Carinthia of this supposedly natural and indivisible unity by quoting the Carinthian journalist and writer Herbert Strutz, an illegal Austrian NSDAP member of the 1930s: "Consider that, if the Carinthians had decided to separate, the border would have gone right through the heart. The border would have severed a natural unity that had grown over centuries." Blaschitz concluded: "Carinthia, ladies and gentlemen, is a naturally grown homeland. Lined by mountains, like a nut in its shell, whoever wanted to divide the kernel—and the danger was immense-would destroy the whole."

Even if such an idea is still present in public discourse in Carinthia, it can be pointed out with regard to contemporary border studies that these kinds of ideas about the supposed nature of a border are socially constructed. Alexandra Schwell (2008: 28) notes: "Borders are social practice and discourse, they are never naturally given. Even seemingly natural borders, such as mountain ranges or rivers, may represent an obstacle, but they only become borders through political, historical, cultural, and social decisions." Borders are thus understood as social and changeable constructs that only emerge as a result of social processes and cognitive distinctions. Peter Weichhart puts it more functionally: "Distinctions, and thus the drawing of boundaries, are not based on the 'nature' of that which is different and its attributes, but are at the discretion of the distinguisher" (Weichhart, 2018: 51). ${ }^{28}$

The assertion of Carinthia's natural and indivisible unity was established in "Carinthian science" after 1920. In 1923, Franz Lex, Viktor Paschinger, and Martin Wutte described "Carinthian unity" in their Landeskunde von Kärnten (Regional Studies of Carinthia) with the following sentence: "In the mountain wall that surrounds it and closes it off from the neighboring countries, Carinthia has a clear, simple, everywhere easily recognizable and sharply separating natural border" (Lex, Paschinger, Wutte, 1923: 224).

Although this argumentation must be considered in the context of the science of its time, it can be understood from the perspective of discourse or dispositif analysis in the specific case as a resource for legitimizing interpretations within German nationalist discourse, which changes with its diachronic course and adapts to its strategic orientation. Thus, during the

27 From Valentin Blaschitz's speech at the 2018 October 10 Celebration in Völkermarkt (authors' recording from minute 3:28).

28 State territories are, in Weichhart's words, a "significant and consequential special case of a socially constructed and constituted space [...]. State territories were also brought into the world at some point through an act of distinction. The distinguishers were powerful actors that were able to enforce their valuation against political rivals" (ibid.: 54). 
Nazi period, there was a short-term reversal of previous assertions or "scientific" descriptions and the "border written in blood" 29 was shifted in the face of political and military facts (in this case, the annexation of Upper Carniola by the Nazi armed forces in 1941).

Martin Fritzl, for example, points to this in his work on the IKLF when he refers to the involvement of the geographer Viktor Paschinger (cf. Fritzl, 1992: 137, 171). In an article published in 1931 in a series in Deutsche Hefte für Volks-und Kulturbodenforschung, Paschinger described the Karawank Mountains as a "structural border" separating two landscapes as "geographically independent spaces" (geochores). The border belt of the Karawanks was functionally by no means a "border mediating traffic and the economy," but it exercised "to a greater degree a necessary protective function" for the north-facing landscape (Paschinger, 1931: 148 ff.; see also Fritzl, 1992: 137). Paschinger's objective in this text, although he explicitly removes the "political point of view" (ibid.: 131) from his analysis, is to classify the division between Carinthia and Carniola (and thus also Yugoslavia) as a natural, transhistorical constant. ${ }^{30}$

After the annexation and incorporation of Upper Carniola into the Nazi Gau of Carinthia, Paschinger's argumentation changed. In a small volume on Upper Carniola from 1942, he refers to the Karawanks, which he had previously called a "structural border" and an "advanced wall against another world" (Paschinger, 1932: 149), "with astonishing flexibility" (Fritzl, 1992: 137), as a "sustainable bridge between two landscapes" (Paschinger, 1942: 7). In this volume, the interpretive pattern of the natural border is still preserved: in the next sentence, Paschinger explains the "political border of Upper Carniola" as "for the most part [...] natural, given by the terrain itself."

Before the annexation of Upper Carniola and the founding of the IKLF, as well as after 1945, the argumentation is similar, at least in the 1937 and 1949 editions of Landeskunde von Kärnten. There the "geographical unity" and individuality of Carinthia and its "natural uniformity” are invoked (cf. Paschinger, 1937: 324 ff., 1949: 401 ff.).

29 The fourth verse of the Carinthian anthem ("Kärntner Heimatlied": "Wo man mit Blut die Grenze geschrieben" 'Where the border was written in blood') is not only sung at all commemoration ceremonies by the German Carinthian commemoration activists in the KHD or the KAB together with visitors at the end of each event, but it is also sung at numerous other official and semi-official occasions. Ute Holfelder has reconstructed the controversies in the politics of remembrance associated with this song and has shown how the dispositif Kärnten/Koroškais created through the function of the Carinthian anthem "as a carrier of meaning for German nationalist interests," but also with the counter-movements in the form of parodies (Holfelder, 2019: $223 \mathrm{ff}$.).

30 In fact, Paschinger's argumentation in this article, which can be assigned to the cultural geography of his time and was at the height of the same, sounds in places very similar to the festive speech from Völkermarkt quoted above, when Paschinger writes about the special unity of the Carinthian landscape and considers: "Just as the geographical unity of Carinthia finds general expression in the concentric shell-like arrangement of the geographical districts around this central landscape, so a study of the landscape structure of Carniola that takes all geo-factors into account would also have to address this land as such a unity" (Paschinger, 1931: 148). However, neither the "geographical unity" of Carinthia nor that of Carniola, which Paschinger still considered worthy of investigation in 1931, are mentioned directly in the 1942 volume on Upper Carniola. 
Fritzl also refers to an article by Paschinger in a commemorative publication of Kulturnachrichten aus Kärnten (Cultural News from Carinthia) published by the Verband für Kultur- und Heimatpflege (Association for the Preservation of Culture and Local History), which was published in 1960 on the fortieth anniversary of the plebiscite. There, without explicitly naming the Karawanks, Paschinger describes the mountain ranges surrounding Carinthia as a "border wall" and evokes the "geographical unity" of Carinthia once again and in analogy to the Landeskunde of 1937 and 1949 (cf. Paschinger, 1960). Fritzl comes to the conclusion that Paschinger belongs to that group of scholars "who interpret their research with astonishing elasticity according to the prevailing political conditions. Whereas in 1942 the aim was to geographically annex Upper Carniola to Carinthia, now the naturalness of the borders - especially those with Slovenia-had to be emphasized again and a national consciousness built on geographic foundations had to be created" (Fritzl, 1992: 172).

What is referred to here as "consciousness" can be described as an interpretive pattern of the natural and indivisible boundary of Carinthia, which has persisted to this day in the hegemonic discourse of the dispositif Kärnten/Koroška, as the quoted 2018 speech in Völkermarkt shows. It is exemplary for many similar statements around the October 10 celebrations in Carinthia. Fritzl also identifies the strategic function at this point: it is about legitimizing the territorial claim against Yugoslavia and Slovenia, at least as long as this is part of the respective (in this case, political and military) agenda.

When we observe a liquefaction of the dispositif Kärnten/Koroškawith regard to the present, the historical initial situation plays an essential role, as does its change, or rather its historical development. This historical development has contributed to the fact that the Grenzland discourse about a possible threat to the territorial border has lost its effectiveness.

\section{LIQUEFACTION OF THE DISPOSITIF KÄRNTEN/KOROŠKA}

Notwithstanding some notable incongruities, ${ }^{31}$ the connections and links in the dispositif Kärnten/Koroška have become fragile. Because the historical, political, and socioeconomic initial situation in Carinthia has changed significantly, we are currently experiencing its liquefaction. The SHS and communist Yugoslavia can no longer be invoked as external threats that allegedly call the territorial border into question. Slovenia, like Austria, is part of the European Union. ${ }^{32}$

31 On the difficulties of this process, see also Fikfak 2015.

32 In fact, the questioning of the border had already been shelved in 1947, in 1949, and at the latest with the co-signing of the State Treaty by Yugoslavia in 1955 (Hellwig, 2001: $14 \mathrm{ff}$.). 


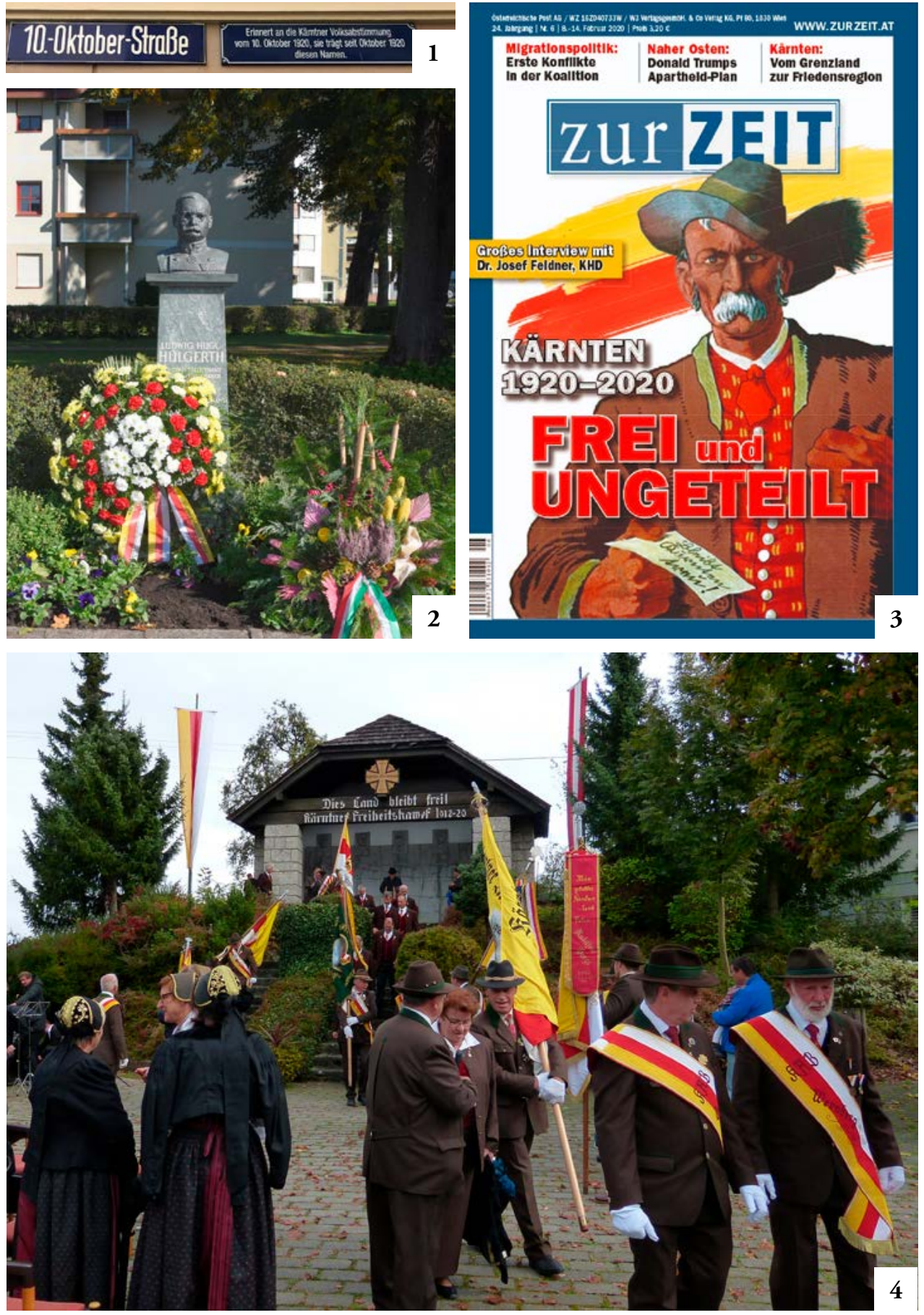

Figures: 1. Street name in Klagenfurt/Celovec (photo by Gabriele Brunner); 2. First Lieutnant Ludwig Hugo Hulgerth (photo by Jurij Fikfak); 3. Cover page of magazine Zur Zeit; 4. "Dies Land bleibt frei!.” St. Jakob in Rosenthal (photo by Klaus Schönberger). 

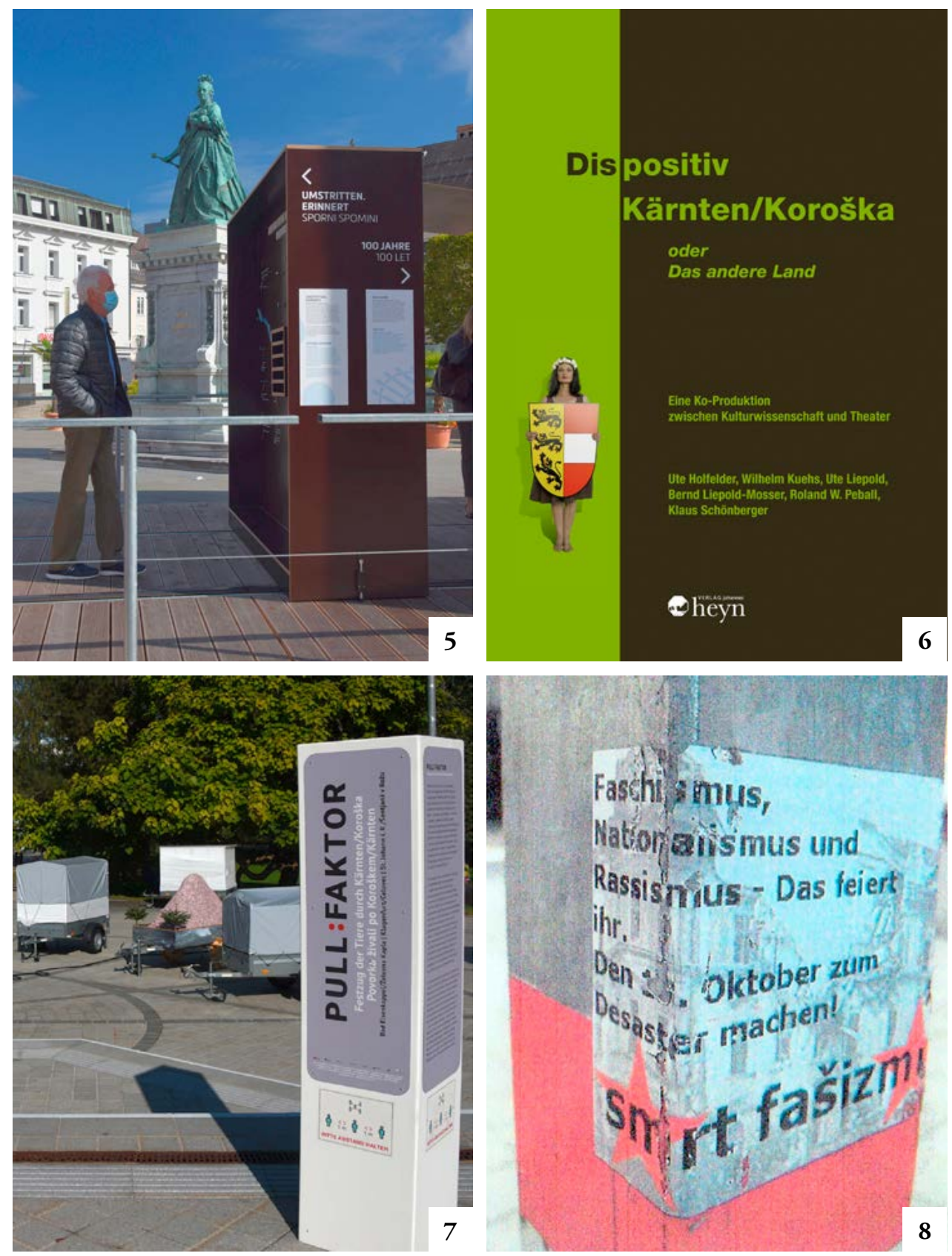

Figures: 5. Exhibition CARINTHIja - Controversial memories (photo by Jurij Fikfak); 6. Cover page of the book Dispositiv Kärnten/Koroška; 7. Animal Festival Train - Pull Faktor - Unikum Production (photo by Jurij Fikfak); 8. "smrt fašizmu" Sticker in Klagenfurt/Celovec 2020. 


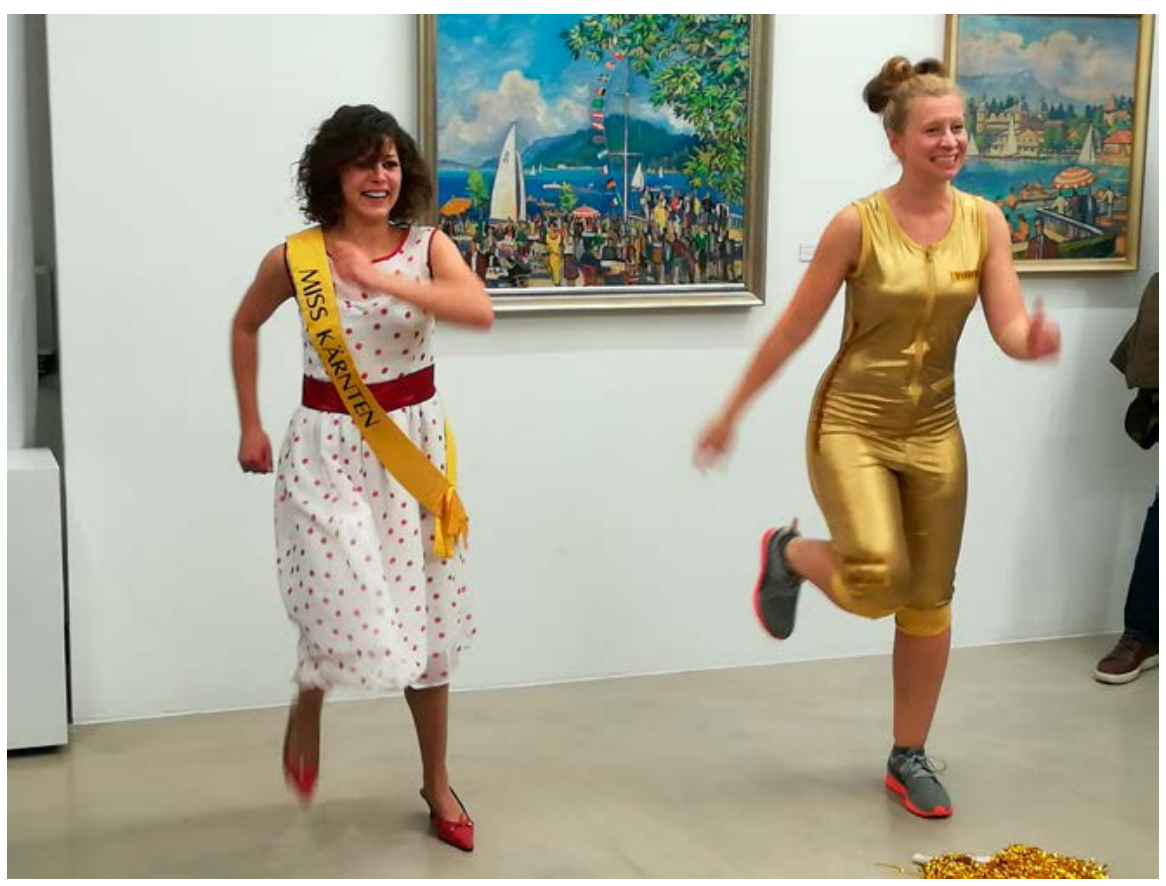

Figure 9. Das Andere Land - Performance (photo by Roland W. Peball).

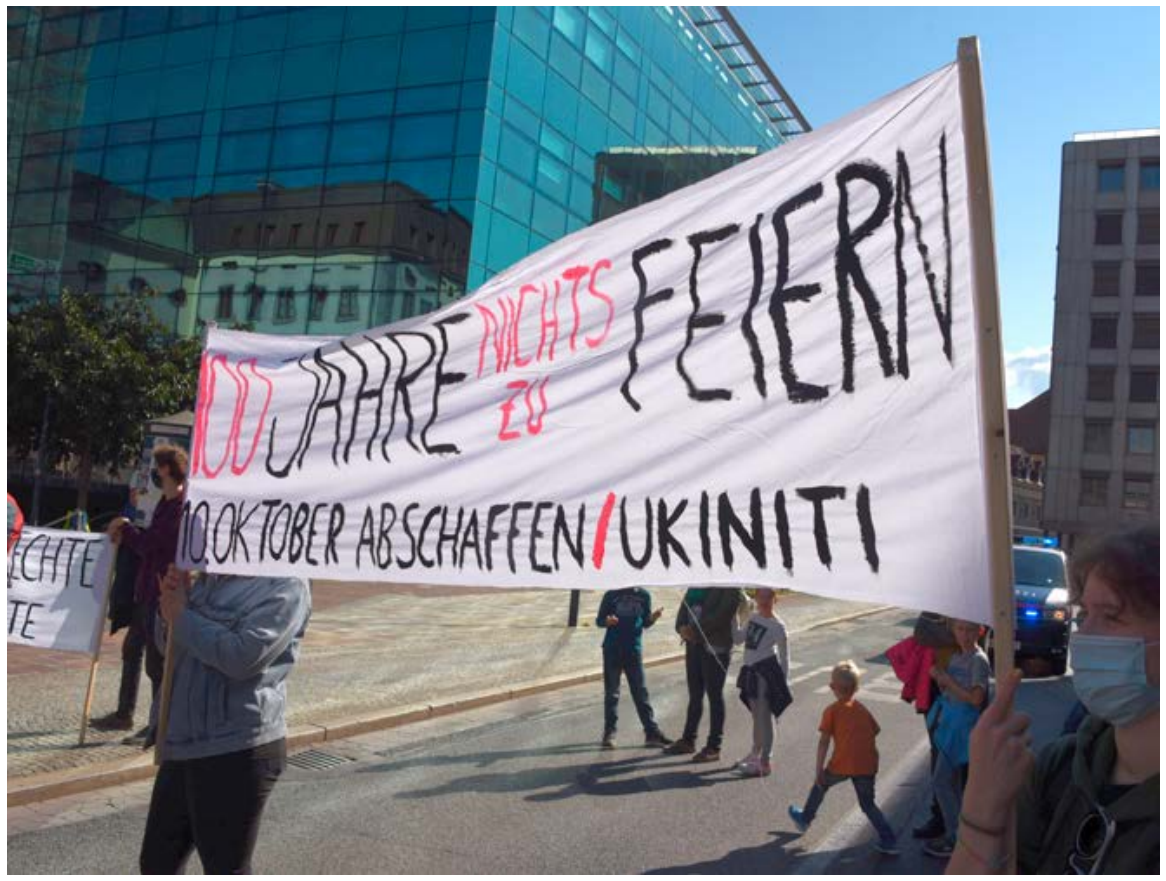

Figure 10. Hundred Years - Nothing to Celebrate! AntiFa demonstration, 10.10.2020 (photo by Jurij Fikfak). 
The idea of the Alps-Adriatic region, ${ }^{33}$ which includes Slovenia, Istria, Styria, Trieste, and the Italian region of Friuli, was already a political project that was able to substantially take the wind out of the sails of the "borderland" discourse. As a result, the dispositifKärnten/ Koroškahas noticeably lost its and has tended to become obsolete as a strategic formation; the external territorial border has thus lost its power of identification and differentiation. Even in parts of the extreme right-wing spectrum, a redefinition is taking place here: "The German Carinthians, on the other hand, with eight million German-speaking people in Austria and almost one hundred million in central Europe behind them, can only harbor irrational fears toward Slovenia. Rationally, there is no longer any real reason to fear any 'Slovenification' of the Carinthian lowlands or even territorial claims" (Mölzer, 2011). However, this is by no means a step toward reformation. The Austrian Freedom Party (FPÖ) ideologist Andreas Mölzer is only trying to get up to speed here when he proposes migration as a substitute in the same text. ${ }^{34}$

The alleged threat of bilingualism has also noticeably lost its mobilizing power. With regard to the minority language, the discourse of the current state government aims at recognition and at least a symbolic appreciation of the second national language in terms of a symbolic ethnicity (Gans, 1979), even if its existence as an everyday language remains massively endangered. Non-migrant multilingualism - in whatever form — now has predominantly positive connotations with regard to professional success and educational advancement. On the one hand, Slovenian is in the process of disappearing (Kolb, 2018), and on the other hand the well-educated part of the Slovenian minority has experienced noticeable social advancement (Obid, 2021). Bilingualism is no longer a stigma, but a qualification.

The weakening or the slow dissolution of the dispositifKärnten/Koroška does not mean that the conflict has ended. Rather, the antagonisms have remained, but they have lost their force of orientation and their former potency (cf. details in Peball, Schönberger, 2021). These changed circumstances mean that today the strategic function of the dispositifis only relevant where it is still useful for the legitimization of one's own history or is indispensable as an ideological orientation for a clientele strongly connected to the antagonistic discourse (such as in the FPÖ).

This circumstance also confronts those actors of the counter-discourse within the Slovenian minority, who in turn need recourse to the discursive definitions by the "hostile" discourse for their own identity designs in order to be able to preserve their uniqueness

33 See the statements of the former SPÖ governor Hans Sima in 1968, who argued "that the existing difficulties can only be overcome by a large-scale politics without violence" (quoted in Hellwig, 2009: 9 ff.).

34 Cf. Mölzer 2011: "In the Republic of Austria, where there have long been immigrant ethnic groups from culturally completely foreign areas, unwilling to integrate and socially very difficult to tolerate, the native Slovenians should have long been regarded without any unease as an integral part of one's own population and one's own culture. There are probably more Chechens and Nigerians in this republic than Carinthian Slovenians." 
(Eigenart) from their point of view. ${ }^{35}$ Discourses about creeping Germanization, but also about the migration of well-educated young people from the Slovenian ethnic group, shift the scales in the discursive field. ${ }^{36}$ Relaxation occurs when Slovenian acquires an increasingly insignificant role in everyday life. Its current recognition and the general appreciation of multilingualism does not change the quasi-assimilation of a large part of the minority. Whereas the ethnic group used to be divided along the lines of Catholic versus left, today this division is shifting toward a confrontation between "reconciliation based on improvements that have occurred" versus "insistence on the realization of the minority rights of Article 7 of the State Treaty that still have not been respected" (Klubs slowenischer Student*innen 2020). Another relevant factor is the demand for an anti-fascist consensus (e.g., in the form of the still outstanding adequate appreciation of the anti-fascist Partisans), which-in view of the fact that in Carinthia there still has been little reappraisal of its involvement in Nazism - represents a major obstacle to a democratic culture of remembrance in Kärnten/ Koroška . The persistent refusal of a fundamental confrontation with the occupation of public space in the form of street names, plaques, or monuments, or with the instrumentalization of folk culture (e.g., the anthem) and so on in the context of Nazism, remains an unrelieved burden in view of the multiple traumatizations of the minority. These are the factors that could keep the dispositif Kärnten/Koroška alive in the foreseeable future. The dichotomy between Kärnten and Koroška cannot be dissolved or even "abolished" in the Hegelian sense. However, the analytical tools of the dispositif open up the possibility of contentious cultural heritages in the Austrian province of Kärnten/Koroška to understand the interconnectedness of the antagonistic discourses and to think about how an "other country" (Holfelder, 2021c) could be shaped.

\section{REFERENCES}

Barth, Fredrik. 1998 (1969). Introduction. In Ethnic Groups and Boundaries: The Social Organization of Cultural Difference, 9-38. Long Gove: Waveland Press.

Bührmann, Andrea D., and Werner Schneider. 2008. Vom Diskurs zum Dispositiv: Eine Einführung in die Dispositivanalyse. Bielefeld: Transcript Verlag. DOI: https://doi.org/10.14361/9783839408186.

Doll, Martin, and Johanna M. Gelberg. 2016. Establishing, Crossing and Expanding Borders. In Spaces and Identities in Border Regions: Politics - Media - Subjects, eds. Christian Wille et al., 15-24. Bielefeld: transcript.

Elste, Alfred. 1996. Eintrag “Alois Maier-Kaibitsch”. In Kärntens braune Elite: 20 biographische Skizzen der „Alten Kämpfer“der NSDAP, 112-120. Klagenfurt: Hermagoras.

35 See, for example, the statement of Verein der Kärntner slowenischen Juristen (2012).

36 Bernard Sadovnik talks in an interview with the Slovenian weekly Novice about the current situation of the Carinthian Slovenians (December 23, 2019; in Gemeinschaft der Kärntner Slowenen und Sloweninnen. https://www.skupnost.at/de/details-1325/interview-mit-bernard-sadovnik-novice.html). 
Fikfak, Jurij. 2015. Political Rituals and Discourses: The Case of Carinthia. Folklore 60: 51-72. http:// www.folklore.ee/folklore/vol60/fikfak.pdf.

Fischer, Gero. 2016. Windischentheorie. In Enzyklopädie der slowenischen Kulturgeschichte in Kärnten/ Koroška: Von den Anfängen bis 1942: Bd. 3, Po-Ž, eds. Katja Sturm-Schnabl and Bojan-Ilija Schnabl, 1519-1520. Wien: Böhlau.

Foucault, Michel. 1972 (1969). The Archeology of Knowledge and the Discourse on Language. London: Tavistock.

Foucault, Michel. 1980. The Confession of the Flesh. In Power/Knowledge: Selected Interviews and Other Writings 1972-1977, ed. Colin Gordon, 194-228. New York: Pantheon.

Foucault, Michel. 1981. The Subject and Power. Critical Inquiry 8 (4): 777-795.

Foucault, Michel. 1988. Technologies of the Self. In Technologies of the Self: A Seminar with Michel Foucault, eds. Luther H. Martin, Huck Gutman and Patrick H. Hutton, 16-49. London: Tavistock.

Foucault, Michel. 1995 (1975). Discipline and Punish: The Birth of the Prison. New York: Vintage.

Fritzl, Martin. 1990. Der Kärntner Heimatdienst: Ideologie, Ziele und Strategien einer nationalistischen Organisation. Klagenfurt/Celovec: Drava.

Fritzl, Martin. 1992. „... für Volk und Reich und deutsche Kultur“: Die „Kärntner Wissenschaft" im Dienste des Nationalismus. Klagenfurt/Celovec: Drava.

Gans, Herbert J. 1979. Symbolic Ethnicity: The Future of Ethnic Groups and Cultures in America. http:// herbertgans.org/wp-content/uploads/2013/11/13-Symbolic-Ethnicity.pdf.

Grafenauer, Danijel. 2016. Vertreibung 1920. In Enzyklopädie der slowenischen Kulturgeschichte in Kärnten/ Koroška: Von den Anfängen bis 1942: Bd. 3, Po-Z̈, eds. Katja Sturm-Schnabl and Bojan-Ilija Schnabl, 1414-1416. Wien: Böhlau.

Hamm, Marion. 2021. Making Heritage Contentious: The Politics of Heritage in Different Configurations. In Contentious Heritages and the Arts: A Critical Companion, eds. Marion Hamm and Klaus Schönberger, 129-160. Klagenfurt/Celovec: Wieser.

Hamm, Marion, and Klaus Schönberger, eds. 2021a. Contentious Heritages and the Arts: A Critical Companion. Klagenfurt: Wieser.

Hamm, Marion, and Klaus Schönberger. 2021b. Signage Dispute in Kärnten/Koroška: Antagonistic Struggles over Language and an Agonistic Turning. In Contentious Heritages and the Arts: A Critical Companion, eds. Marion Hamm and Klaus Schönberger, 177-186. Klagenfurt/Celovec: Wieser.

Hamm, Marion, and Janine Schemmer. 2021. Silenced Memories and Practices of Un-Silencing: Mobilities in a Dynamic Alpine Border-Landscape. Cultural Analysis 19 (1):24-48. https://www.ocf.berkeley. edu/ culturalanalysis/volume19_1/pdf/HammSchemmer.pdf.

Hellwig, Valentin. 2009. Der Sonderfall: Kärntner Zeitgeschichte 1918-2004/08. Klagenfurt/Celovec: Hermagoras.

Holfelder, Ute. 2019. “Where Salzburg borders on Tyrol...”: The Carinthian Anthem and the Construction of the Dispositif Kärnten/Koroška.Journal of European Ethnology and Cultural Analysis 4 (2):210-230.

Holfelder, Ute. 2020. Umstrittenes Kulturerbe: Öffentliche Erinnerungszeichen in Klagenfurt/Celovec. In Sprehod po Klagenfurtu 1920 | 2020 Spaziergang durch Celovec: Erkundungen zum 10. Oktober 1920 in Klagenfurt/Celovec, eds. Ute Holfelder et al., 5-14. Klagenfurt/Celovec: Drava.

Holfelder, Ute. 2021a. Die 10.-Oktober-Feiern in Kärnten/Koroška als umstrittenes Kulturerbe. Österreichische Zeitschrift für Volkskunde 75/124 (1): 5-36.

Holfelder, Ute. 2021b. Diskurs/THEATER: The Other Land: Dis- and Re-Articulating the Dispositif Kärnten/Koroška. In Contentious Heritages and the Arts: A Critical Companion, eds. Marion Hamm and Klaus Schönberger, 186-196. Klagenfurt/Celovec: Wieser. 
Holfelder, Ute, and Klaus Schönberger. 2020. Die Besetzung der Landschaft - Contentious Cultural Heritages in Kärnten/Koroška: Anmerkungen zur kulturellen Grammatik der Erinnerung an den 10. Oktober. In Kärntner Jabrbuch für Politik, 209-221. Klagenfurt: Hermagoras.

Holfelder, Ute et al. 2021. Dispositiv Kärnten/Koroška - Disartikulation - Re-Artikulation und Verflüssigung. Zur Möglichkeit der Zusammenarbeit von Theater und Kulturanalyse. In Ko-Produktion von Ethnografie und Performativen Künsten - Zur Diskussion um künstlerische und wissenschaftliche Forschung, eds. Ute Holfelder, Roland W. Peball and Klaus Schönberger. Münster: Waxmann. [Forthcoming]

Jodlbaur, Ralph. 1996. Die Kärntner Slowenen. In Handbuch der mitteleuropäischen Sprachminderheiten, eds. Robert Hinderling and Ludwig M. Eichinger, 119-165. Tübingen: Narr.

Keller, Reiner. 2011. Wissenssoziologische Diskursanalyse: Grundlegung eines Forschungsprogramms. Wiesbaden: Springer.

Knight, Robert. 2020. Politik der Assimilation: Österreich und Kärntner Slowenen nach der NS-Herrschaft. Wien, Hamburg: New Academic Press.

Kolb, Jonas. 2018. Präsenz durch Verschwinden: Sprache und Ethnizität in der Alltagspraxisjunger Kärntner Slowen_innen. Bielefeld: Transcript.

Kuehs, Wilhelm. 2020. Macht. Hegemonie. Geschichtsschreibung: Zur Okkupation des geschichtswissenschaftlichen Diskurses zum Kärntner Plebiszit durch die Politik. In Dispositiv Kärnten/Koroška oder Das andere Land: Eine Ko-Produktion zwischen Kulturwissenschaft und Theater, eds. Bernd Liepold-Mosser et al., 64-87. Klagenfurt: Heyn.

Landry, Rodrogie, and Richard Y. Bourhis. 1997. Linguistic Landscape and Ethnolinguistic Vitality: An Empirical Study. Journal of Language and Social Psychology 16 (1): 23-49. DOI: https://doi. org/10.1177/0261927X970161002.

Larcher, Dietmar. 1988. „Der Kärntner spricht Deutsch “: Bemerkungen zum Sterben einer zweisprachigen Kultur. Sprachreport 4: 8-10. https://ids-pub.bsz-bw.de/frontdoor/index/index/docId/9410.

Liepold-Mosser, Bernd. 2020. Dispositiv Kärnten/Koroška: Ein Essay. In Dispositiv Kärnten/Koroška oder Das andere Land: Eine Ko-Produktion zwischen Kulturwissenschaft und Theater, eds. Bernd LiepoldMosser et al., 10-63. Klagenfurt: Heyn.

May, Stefan. 2020. Das Misstrauen bleibt: Kärnten und seine slowenische Minderheit. In Deutschlandfunk Kultur: Zeitfragen, July 20. https://www.deutschlandfunkkultur.de/kaernten-und-seine-slowenische-minderheit-das-misstrauen.976.de.html?dram:article_id=481007.

Moser, Manfred. 1982. Sprachliche und soziale Identität der Slowenen in Kärnten. In Kein einig Volk von Brüdern. Studien zum Mehrbeiten/Minderheitenproblem am Beispiel Kärntens, ed. Franz Dotter, 16-34. Wien: Verlag für Gesellschaftskritik.

Mouffe, Chantal. 2007. Überdas Politische: Wider die kosmopolitische Illusion. Frankfurt am Main: Suhrkamp.

Nemec, Birgit. 2012. Das Um-Schreiben urbaner Topographien - Gedächtnispolitik durch Straßenumbenennungen. Wien, 1910-2010. In Update! Perspektiven der Zeitgeschichte, eds. Linda Erker et al., 672-680. Wien: Studien Verlag.

Niethammer, Lutz. 2000. Kollektive Identität: Heimliche Quellen einer unheimlichen Konjunktur. Reinbek: Rowohlt.

Nowicka, Magdalena. 2013. Ist Dispositiv nur ein Modebegriff?: Zur Poetik des, dispositif turns'. In Verortungen des Dispositiv-Begriffs: Theorie und Praxis der Diskursforschung, eds. Joannah Wengler, Britta Hoffarth and Łukasz Kumięga, 36-54. Wiesbaden: Springer. DOI: https://doi. org/10.1007/978-3-531-94260-5_3. 
Obid, Milan. Forthcoming. Is 'symbolic ethnicity' the future of the Slovene minority in Austria? In Societies and Spaces in Contact: Between Convergence and Divergence. Studies in European Integration, State and Society, eds. Milan Bufon, Tove Malloy and Colin Williams. Berlin: Peter Lang.

Peball, Roland, and Klaus Schönberger. 2021. Anfangund Ende des Dispositivs Kärnten/Koroška: Deutungskämpfe und Erinnerungspolitiken als Contentious Cultural Heritages. [In print.]

Pelinka, Anton. 2004. Kärnten - ein europäischer Sonderfall. In Ortstafelkonflikt in Kärnten - Krise oder Chance?, ed. Martin Pandel, 103-113. Wien: Braumüller.

Perchinig, Bernhard. 1984. „Wir sind Kärntner und damit hat sich's...": Deutschnationalismus und politische Kultur in Kärnten. Klagenfurt: Drava.

Pluch, Thomas. 1957. Das Kärntner Plebiszit des Jahres 1920. Dissertation. Wien.

Schönberger, Klaus. 2021a. Of Hushing Up and Remembering - Partisans in Carinthia. In Contentious Heritages and the Arts: A Critical Companion, eds. Marion Hamm and Klaus Schönberger, 207-214. Klagenfurt/Celovec: Wieser.

Schönberger, Klaus. 2021b. ,... der in meinem Auftrag erfolgten Erschießung“: Hans Steinacher - ein Kärntner ,Held' als Agent des völkischen Terrorismus. In 100. obletnica plebiscita na Koroškem: Zgodovinske izkušnje in pogledv pribodnost / 100 Jahre Kärntner Volksabstimmung: Historische Erfahrungen und Blick in die Zukunft, ed. Danijel Grafenauer. Ljubljana: Slovenska Matica. [In print.]

Schönberger, Klaus. 2021c. Mythos Hans Steinacher als Antagonismus: Gedenkpraktiken in Kärnten/Koroška. Osterreichische Zeitschrift für Volkskunde. [In print.]

Schwell, Alexandra. 2008. Europa an der Oder: Die Konstruktion europäischer Sicherheit an der deutschpolnischen Grenze. Bielefeld: transcript.

Schwell, Alexandra. 2021. (Un-)Sicherheit und Grenzen. In Grenzforschung: Handbuch für Wissenschaft und Studium, eds. Dominik Gerst, Maria Klessmann and Hannes Krämer, 267-282. Baden-Baden: Nomos Verlagsgesellschaft. DOI: https://doi.org/10.5771/9783845295305-267.

Tiemann Guido. 2020. „Kärnten“ = Austria, „Koroska“ = Yugoslavia?: Some Revisionist Perspectives on the 1920 Carinthian Plebiscite. Historical Social Research 45 (4): 300-347. https://www.jstor.org/ stable/26956103.

Wagner, Klemens, and Jan David Zimmermann. 2020. Neue Arbeit an historischem Material: Der Atlas des umstrittenen Dialektologen Eberhard Kranzmayer aus wissenschaftshistorischer Perspektive. DiÖ-Online. https://dioe.at/details/artikel/2379/.

Weichhart, Peter. 2018. Grenzen, Territorien und Identitäten. In Grenzen: Theoretische, konzeptionelle und praxisbezogene Fragestellungen zu Grenzen und deren Überschreitungen, eds. Martin Heintel, Robert Musil and Norbert Weixelbaumer, 43-63. Wiesbaden: VS.

\section{SOURCES}

Blaschitz, Valentin. 2018. Speech at the 10 October celebrations in Völkermarkt, October 9, 2018, M4A recording and transcript.

Brunner, Katharina. 2020. Die verdrängte Sprache. In DATUM - Seiten der Zeit, November 2020. https:// datum.at/die-verdraengte-sprache/.

Feldner, Josef. 1982. Grenzland Kärnten: Kärntner Weissbuch: 2. Teil. Klagenfurt: Heyn.

Hellwig, Valentin. 2001. Kärntner Landesgeschichte. Kärnten 1918 - 2000: Daten und Fakten zur Zeitgeschichte. Onlinepublication. Klagenfurt: Kärntner Verwaltungsakademie. 
Klubs slowenischer Student*innen in Kärnten/Koroška, Graz/Gradec und Wien/Dunaj (KSŠŠD/KSŠŠK/ KSŠŠK). 2020. 100 Jahre nichts zu feiern: Aspekte antislowenischer Kontinuität in Kärnten/Koroška. Dunaj/Wien, Gradec/Graz, Celovec/Klagenfurt: Self-published.

Lausegger, Josef. 2009. Das linke Erbe der Partisanen. Die Kärntner Landsmannschaft 2009 (2): 3-6.

Lagger, Hans. 1930. Abwehrkampf und Volksabstimmung in Kärnten 1918 bis 1920. Hrsg. im Auftrag der sozialdemokratischen Landesparteivertretung Kärntens. Klagenfurt: Verlag der sozialdemokratischen Landesparteivertretung Kärnten.

Lex, Franz, Viktor Paschinger, and Martin Wutte. 1923. Landeskunde von Kärnten. Klagenfurt: Gutenberghaus W. Merkel.

Mölzer, Andreas. 2011. Wann kehrt in Kärnten europäische Normalität ein? Die Slowenen sind Bestandteil der eigenen Kultur (Gastkommentar). Kleine Zeitung, April 5.

Paschinger, Viktor. 1932. Die Karawanken als Strukturgrenze. Deutsche Heftefür Volks-und Kulturbodenforschung 1931/32 (2): 130-149.

Paschinger, Viktor. 1937. Landeskunde von Kärnten. Klagenfurt: Gutenberghaus.

Paschinger, Viktor. 1949. Landeskunde von Kärnten und Osttirol. $2^{\text {nd }}$ Ed. Klagenfurt: Kärntner Heimatverlag.

Paschinger, Viktor. 1960. Die geographische Einheit Kärntens. In Festschrift herausgegeben aus Anlaß der 40. Wiederkehr des Tages der Kärntner Volksabstimmungvom 10. Oktober 1920, 15-16. Klagenfurt: Verband für Kultur- und Heimatpflege Kärntens.

Paschinger, Viktor, Martin Wutte, and Georg Graber. 1942. Oberkrain. Krainburg: Gaupresseamt d. NSDAP.

Paschinger, Viktor. 1942. Land und Wirtschaft. In Oberkrain, eds. Viktor Paschinger, Martin Wutte and Georg Graber, 7-35. Krainburg: Gaupresseamt d. NSDAP.

Alexander Van der Bellen: Rede von Bundespräsident beim Festakt „100 Jahre Kärntner Volksabstimmung“, 10. Oktober 2020, Klagenfurt. In Österreichische Präsidentschaftskanzlei. https://www.bundespraesident.at/fileadmin/user_upload/100_Jahre_Kaerntner_Volksabstimmung_DEU_formatiert.pdf.

Verein der Kärntner slowenischen Juristen. 2012². Volksgruppengesetz 2011: Eine Kritik. In Kärnten liegt am Meer: Konfliktgeschich-te/n über Trauma, Macht und Identität, eds. Wolfgang Petritsch, Wilfried Graf and Gudrun Kramer, 405-422. Klagenfurt/Celovec: Drava.

\section{TERITORIALNE IN JEZIKOVNE RAZMEJITVE V DISPOZITIVU KÄRNTEN/KOROŠKA}

Na južnem Koroškem (Kärnten/Koroška) že stoletje tli konflikt o zatiranju in pravicah slovensko govoreče manjšine. Spor se osredinja predvsem na spomin in komemoracijo vojaškega obmejnega spopada 1918/19 in plebiscita, ki ga je potrdila senžermenska pogodba. Ko so se po 1. svetovni vojni pojavile države naslednice Avstro-Ogrske, je ta vojaški spopad potekal med silami, lojalnimi Kraljevini Srbov, Hrvatov in Slovencev (SHS), nemško-avstrijskimi zasebnimi paravojaškimi skupinami (Freikorps) in lokalnimi obrambnimi paravojaškimi skupinami (Heimwehr) ali socialdemokratskimi delavskimi bataljoni. Plebiscit se je nanašal na vprašanje, ali naj se južna Koroška priključi okrnjeni habsburški monarhiji, tj. nemški Avstriji, ali novoustanovljeni 
državi SHS. Leta 1920 se je večina tamkajšnjega prebivalstva (tako pripadniki nemške kot slovenske skupnosti) odločila za Avstrijo. V naslednjih desetletjih, vse do Jörga Haiderja (kot koroškega glavarja), so se nemško nacionalistično usmerjeni zastopniki nemške koroške večine neusmiljeno borili proti jeziku in spominu slovenske manjšne. Z opravičilom manjsini, ki ga je avstrijski predsednik Alexander van der Bellen v govoru ob stoletnici plebiscita 10. oktobra $2020 v$ navzočnosti slovenskega predsednika izrekel koroškim Slovencem zaradi neupoštevanja pravnih zahtev, številnih odlogov in izključevanj, se morda zdaj nakazuje prelomnica. Članek analizira tematizacijo jezikovnih in teritorialnih razmejitev z vidika dispozitiva Kärnten/ Koroška. Eno od vprašanj je, kakšno analitično moč ima predloženi teoretski koncept tega dispozitiva tako za genealogijo kot za transformacije konflikta.

Roland W. Peball, Alpe-Adria University, Klagenfurt/Celovec, roland.peball@aau.at

Prof. Dr. Klaus Schoenberger, Alpe-Adria University, Klagenfurt/Celovec, klaus.schonberger@aau.at 